\section{THE STRUCTURE AND CYTOCIDAL ACTIVITY OF HERBIMYCIN C}

Sir:

Herbimycins $\mathrm{A}^{1 \sim 3)}$ (1) and $\mathrm{B}^{4)}$ (2), new benzoquinoid ansamycin antibiotics isolated from the culture broth of Streptomyces hygroscopicus AM-3672, possess herbicidal, anti-tobacco mosaic virus and antitumor activities. Recently, Uehara et al.,5) have reported that the antibiotics convert the transformed morphology of Rous sarcoma virus-infected rat kidney cells to the normal one. During the course of the investigation of production of $\mathbf{1}$ and $\mathbf{2}$, an antibiotic, herbimycin C (3) was found in the culture broth. In this communication, we wish to describe the isolation, structure elucidation and cytocidal activity of 3 .

Fermentation was carried out under the conditions reported previously. ${ }^{1)}$ The cultured broth (15 liters) was centrifuged and the supernatant was extracted twice with EtOAc. After evaporation of the extract, the residue was chromatographed on an activated charcoal column using $20 \sim 30 \%$ aq acetone and then on a silica gel column using benzene - acetone, $5: 1$ to afford a yellowish amorphous powder of 3 $(28.8 \mathrm{mg})$ in addition to $\mathbf{1}(650.1 \mathrm{mg})$. Antibiotic 3: MP $203^{\circ} \mathrm{C}(\mathrm{dec}) ;[\alpha]_{\mathrm{D}}^{23}+210^{\circ}(c \quad 0.5$,
$\mathrm{CHCl}_{3}$ ); high resolution EI-MS $\mathrm{m} / \mathrm{z} 560.273$ (calcd for $\mathrm{C}_{29} \mathrm{H}_{40} \mathrm{~N}_{2} \mathrm{O}_{9}: 560.273$ ), is considered to be structurally similar to $\mathbf{1}$ and $\mathbf{2}$ from its UV and IR spectra. The UV spectrum of $\mathbf{3}$ in $\mathrm{MeOH}$ exhibited absorptions at $269 \mathrm{~nm}(\varepsilon 19,000)$ and $395 \mathrm{~nm}(\varepsilon 2,300)$, corresponding to a benzoquinoid moiety. The IR spectrum $(\mathrm{KBr})$ of 3 showed absorptions at $1730 \mathrm{~cm}^{-1}$ (carbamoyl), $1695 \mathrm{~cm}^{-1}$ (quinone carbonyl) and $1660 \mathrm{~cm}^{-1}$ (amide carbonyl). The ${ }^{13} \mathrm{C}$ NMR spectrum $\left(100 \mathrm{MHz}\right.$ in $\left.\mathrm{CDCl}_{3}\right)$ of 3 showed the presence of twenty nine carbon signals [seven methyls, one methylene, seven methines including five carbons bonded to an oxygen, ten olefinic

Chart 1.

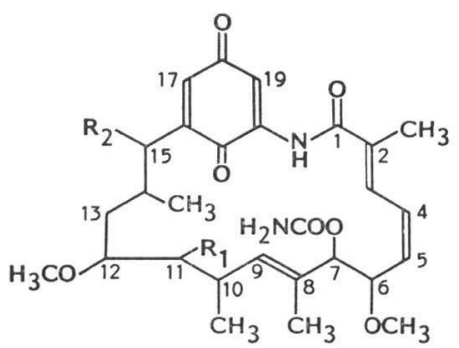

Herbimycin $A$ (1) $\mathrm{R}_{1}=\mathrm{OCH}_{3} \quad \mathrm{R}_{2}=\mathrm{OCH}_{3}$ Herbimycin $B$ (2) $\mathrm{R}_{1}=\mathrm{OH} \quad \mathrm{R}_{2}=\mathrm{H}$ Herbimycin C (3) $\mathrm{R}_{1}=\mathrm{OH} \quad \mathrm{R}_{2}=\mathrm{OCH}_{3}$

Fig. 1. ${ }^{1} \mathrm{H}$ NMR spectrum of herbimycin $\mathrm{C}(3), 400 \mathrm{MHz}, \mathrm{CDCl}_{3}$.

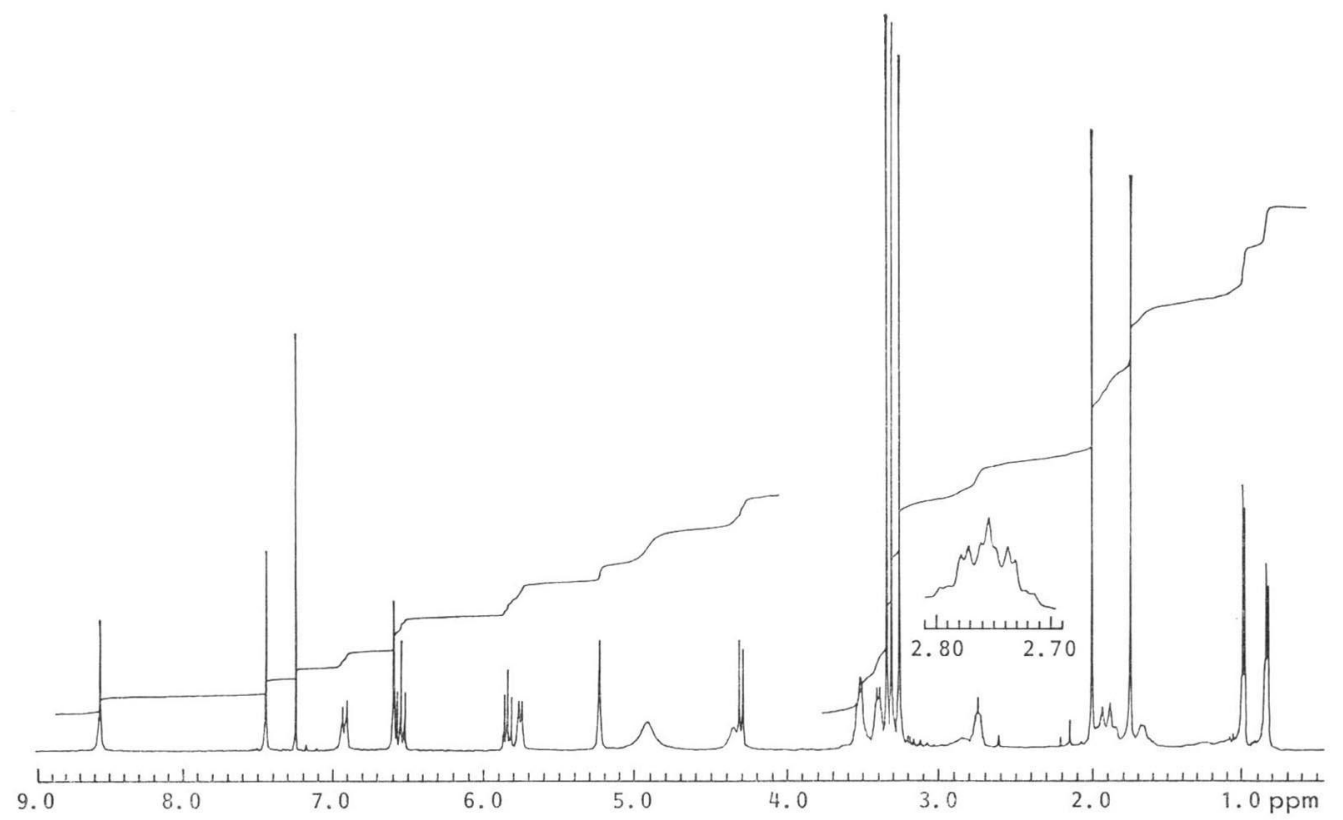


Table 1. ${ }^{1} \mathrm{H}$ and ${ }^{13} \mathrm{C}$ chemical shift values of herbimycins.

\begin{tabular}{|c|c|c|c|c|c|c|}
\hline \multirow{2}{*}{$\begin{array}{c}\text { Carbon } \\
\text { No. }\end{array}$} & \multicolumn{2}{|c|}{ Herbimycin C (3)* } & \multirow{2}{*}{$\begin{array}{c}\text { Herbimycin } \\
\text { A (1) } \\
{ }^{13} \mathrm{C}\end{array}$} & \multirow{2}{*}{$\begin{array}{c}\text { Herbimycin } \\
\text { B (2) } \\
{ }^{13} \mathrm{C}\end{array}$} & \multicolumn{2}{|c|}{$\begin{array}{c}\text { Monoacetylherbimycin } \\
\text { C (4)** }\end{array}$} \\
\hline & ${ }^{1} \mathrm{H}$ & ${ }^{13} \mathrm{C}$ & & & ${ }^{1} \mathrm{H}$ & ${ }^{13} \mathrm{C}$ \\
\hline 1 & $8.58 \mathrm{~s}$ & 168.2 & 168.7 & 169.1 & $8.80 \mathrm{~s}$ & 169.0 \\
\hline 2 & & 134.8 & 134.5 & 133.1 & & 135.2 \\
\hline 3 & 6.93 br d & 127.2 & 128.2 & 128.3 & 6.97 br d & 128.6 \\
\hline 4 & $6.56 \mathrm{dd}$ & 126.3 & 125.6 & 125.6 & $6.50 \mathrm{t}$ & 126.2 \\
\hline 5 & $5.85 \mathrm{t}$ & 136.2 & 136.7 & 133.7 & $5.86 \mathrm{dd}$ & 137.1 \\
\hline 6 & $4.31 \mathrm{~d}$ & 81.2 & 78.3 & 81.5 & 4.57 br d & 76.0 \\
\hline 7 & $5.24 \mathrm{~s}$ & 80.7 & 79.2 & 80.6 & 5.72 br s & 78.2 \\
\hline 8 & & 133.4 & 131.6 & 132.5 & & 132.7 \\
\hline 9 & 5.77 br d & 132.7 & 130.1 & 131.8 & 5.36 br d & 133.2 \\
\hline 10 & $2.76 \mathrm{ddd}$ & 32.6 & 34.1 & 32.0 & $2.71 \mathrm{~m}$ & 34.8 \\
\hline 11 & $3.40 \mathrm{~m}$ & 72.9 & 82.3 & 71.7 & $5.15 \mathrm{dd}$ & 75.1 \\
\hline 12 & $3.53 \mathrm{~m}$ & 81.2 & 83.4 & 80.0 & $3.62 \mathrm{~m}$ & 78.6 \\
\hline 13 & $1.95 \mathrm{~m}$ & 33.8 & 34.0 & 30.4 & $1.80 \mathrm{~m}$ & 34.1 \\
\hline 14 & $1.68 \mathrm{~m}$ & 32.1 & 36.7 & 26.1 & $1.60 \mathrm{~m}$ & 37.5 \\
\hline 15 & $4.37 \mathrm{br} \mathrm{s}$ & 80.5 & 78.7 & 30.4 & 4.51 br s & 81.0 \\
\hline 16 & & 143.9 & 144.6 & 145.1 & & 145.3 \\
\hline 17 & $6.61 \mathrm{dd}$ & 132.9 & 132.6 & 134.6 & $6.60 \mathrm{dd}$ & 133.2 \\
\hline 18 & & 187.7 & 187.7 & 187.8 & & 187.8 \\
\hline 19 & $7.45 \mathrm{~d}$ & 113.6 & 112.9 & 112.2 & $7.32 \mathrm{~d}$ & 113.0 \\
\hline 20 & & 138.3 & 138.2 & 140.2 & & 138.5 \\
\hline 21 & & 185.0 & 183.9 & 182.4 & & 184.2 \\
\hline $2-\mathrm{CH}_{3}$ & $2.01 \mathrm{br} \mathrm{s}$ & 12.6 & 12.4 & 12.4 & 2.02 br s & 12.2 \\
\hline $6-\mathrm{OCH}_{3}$ & $3.31 \mathrm{~s}$ & 56.6 & 56.0 & 56.0 & $3.33 \mathrm{~s}$ & 56.1 \\
\hline 7-OCONH & 4.93 br s & 156.0 & 155.9 & 155.9 & $4.70 \mathrm{~s}$ & 155.6 \\
\hline $8-\mathrm{CH}_{3}$ & 1.77 br s & 12.7 & 14.1 & 12.5 & 1.73 br s & 14.2 \\
\hline $10-\mathrm{CH}_{3}$ & $1.00 \mathrm{~d}$ & 14.4 & 16.3 & 23.3 & $1.00 \mathrm{~d}$ & 16.3 \\
\hline $11-\mathrm{OCH}_{3}$ & & & 58.4 & & & \\
\hline $12-\mathrm{OCH}_{3}$ & $3.26 \mathrm{~s}$ & 57.1 & 57.6 & 56.5 & $3.29 \mathrm{~s}$ & 57.8 \\
\hline $14-\mathrm{CH}_{3}$ & $0.85 \mathrm{~d}$ & 13.0 & 13.6 & 12.9 & $0.84 \mathrm{~d}$ & 13.3 \\
\hline $15-\mathrm{OCH}_{3}$ & $3.35 \mathrm{~s}$ & 58.5 & 59.8 & & $3.36 \mathrm{~s}$ & 58.7 \\
\hline
\end{tabular}

Chemical shifts in ppm are down field from $\left(\mathrm{CH}_{3}\right)_{4} \mathrm{Si} .{ }^{1} \mathrm{H}$ and ${ }^{13} \mathrm{C}$ NMR spectra were measured in $\mathrm{CDCl}_{3}$ with a Varian XL-400.

$* 11-\mathrm{OH}=\delta_{\mathrm{H}} 2.85 . * * 11-\mathrm{OCOCH}_{3}: \delta_{\mathrm{H}} 1.89, \delta_{\mathrm{C}} 21.1$ and 171.0.

carbons and four carbonyl carbons (amide, carbamoyl and quinone)]. In the comparison of the ${ }^{13} \mathrm{C}$ NMR spectrum of $\mathbf{3}$ with that of $\mathbf{1}$, the chemical shift value for each carbon signal arising from the ansa chain moiety in $\mathbf{3}$, except for the signal at $\mathrm{C}-11$, was coincident with that of $\mathbf{1}$. The signal assigned to $\mathrm{C}-11$ in 3 appeared to shift to a higher field at $\delta_{\mathrm{C}} 72.9(\Delta 9.4 \mathrm{ppm})$ compared with that of $\mathbf{1}$ in which a methoxyl group was attached. This means that a hydroxyl group is located at the C-11 in $\mathbf{3}$ as in $\mathbf{2}$. The structure of $\mathbf{3}$ was confirmed from the NMR spectrum of monoacetylherbimycin C (4): MP $169^{\circ} \mathrm{C}(\mathrm{dec}) ;[\alpha]_{\mathrm{D}}^{23}+204^{\circ}\left(c 0.5, \mathrm{CHCl}_{3}\right)$; high resolution EI-MS $\mathrm{m} / \mathrm{z} 602.283$ (calcd for $\left.\mathrm{C}_{31} \mathrm{H}_{42} \mathrm{~N}_{2} \mathrm{O}_{10}, 602.284\right) ;{ }^{1} \mathrm{H} \quad \mathrm{NMR} \quad \delta_{\mathrm{H}} \quad 1.89$
$\left(\mathrm{OCOCH}_{3}\right)$, which was obtained by acetylation of 3 with acetic anhydride in pyridine. In the ${ }^{1} \mathrm{H}$ NMR spectra of 3 and 4 , the signal at $\delta_{\mathrm{H}}$ 3.40 assigned to the $\mathrm{H}-11$ in $\mathbf{3}$ showed low field shift to $\delta_{\mathrm{H}} 5.15(\Delta 1.65 \mathrm{ppm})$ by acetylation. A similar shift $(\Delta 2.2 \mathrm{ppm})$ from $\delta_{\mathrm{C}} 72.9$ at C-11 in 3 to $\delta_{\mathrm{C}} 75.1$ in $\mathbf{4}$ was observed. In the COSY spectrum of 4 , the signal at $\delta_{\mathrm{H}} 2.71(\mathrm{H}-10)$ is correlated with the signals at $1.00 \mathrm{~d}, J=6.8$ $\mathrm{Hz}, 10-\mathrm{CH}_{3}$ ), 5.36 (br d, $J=9.5 \mathrm{~Hz}, \mathrm{H}-9$ ) and 5.15 (dd, $J=9.0$ and $1.5 \mathrm{~Hz}, \mathrm{H}-11$ ). Further, the signal at $\delta_{\mathrm{H}} 5.15$ is correlated to the signal at $\delta_{\mathrm{H}} 3.62(\mathrm{~m}, \mathrm{H}-12)$. Therefore, the structure of 3 was elucidated at 11-hydroxy-11-demethoxyherbimycin A. Antibiotic 3 is the same compound with TAN 420-D which was obtained by 
Fig. 2. Cytocidal activity of herbimycins on HeLa and Ehrlich cells.

HeLa S3 and Ehrlich cells were maintained in monolayers in EAGLE's minimum essential medium supplemented with $10 \%$ bovine serum and kanamycin $(100 \mu \mathrm{g} / \mathrm{ml})$ at $37^{\circ} \mathrm{C}$. To determine the cytotoxicity of herbimycins, HeLa S3 or Ehrlich cells $\left(5 \times 10^{4}\right)$ in $1.5 \mathrm{ml}$ of medium were placed in a tissue culture plate (Falcon, 24-well) and incubated for 24 hours at $37^{\circ} \mathrm{C}$ in a $5 \% \mathrm{CO}_{2}-95 \%$ air atmosphere. Each culture well was added with $0.5 \mathrm{ml}$ of fresh medium containing a different concentration of herbimycins, and reincubated for 72 hours. The cells were trypsinized to form a single cell suspension, and were counted in a hemocytometer.

- Herbimycin A, herbimycin B, herbimycin C.

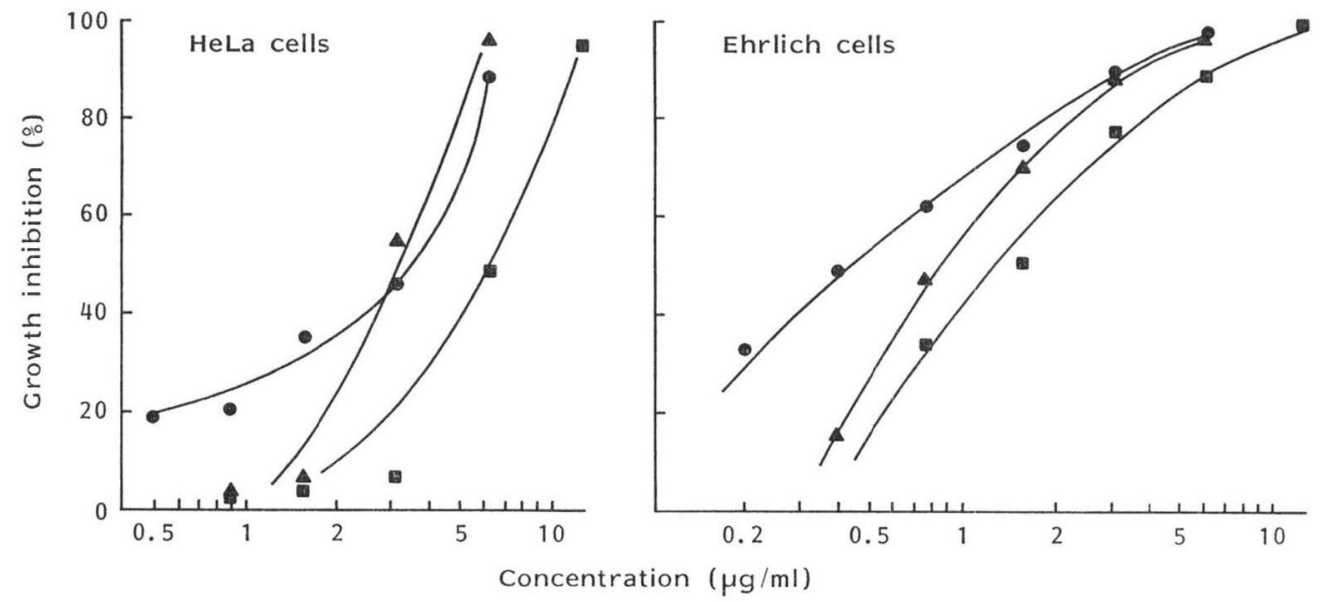

oxidation of the EtOAc extract from the culture filtrate of $S$. hygroscopicus. ${ }^{6 \sim 8)}{ }^{1} \mathrm{H}$ and ${ }^{13} \mathrm{C}$ chemical shift values of 3 and its related compounds were assigned as shown in Table 1.

Herbimycins A, B and C showed cytocidal activity on both HeLa cells and Ehrlich cells in vitro (Fig. 2). The $\mathrm{IC}_{50} \mathrm{~s}$ of herbimycins were as follows; A 3.5, B 3.2, C 7.3 on HeLa cells and A 0.4, B 0.8, C $1.2 \mu \mathrm{g} / \mathrm{ml}$ on Ehrlich cells. The exchange of hydroxyl group instead of methoxyl group at the $\mathrm{C}-11$ position decreases the activity. Antibiotic $\mathbf{3}$ was weakly active against Piricularia oryzae and Trichophyton rubrum but inactive against various bacteria tested like other benzoquinoid ansamycins such as herbimycins A and $\mathrm{B}^{4)}$ and geldanamycin. ${ }^{2)}$ The herbicidal activity of $\mathbf{3}$ is under examination.

\section{Acknowledgments}

The authors wish to thank Mrs. Akiko Hatano and Michiкo Sato for $400 \mathrm{MHz}$ NMR spectroscopy, and Miss Kimie Furuta for her helpful assistance. This work was supported by fund from the Japan Keirin Association.

\section{Kiyoshi SHibata}

SADAYOSHI SATSUMABayashi AKIRA NAKAGAWA ${ }^{\dagger}$ SATOSHI ŌMURA $*,+$
Nippon Dental University, Chiyoda-ku, Tokyo 102, Japan

${ }^{\top}$ The Kitasato Institute and School of Pharmaceutical Sciences, Kitasato University, Minato-ku, Tokyo 108, Japan

(Received June 2, 1986)

\section{References}

1) Ōmura, S.; Y. Iwai, Y. Takahashi, N. SadaKane, A. NaKagaWa, H. ŌIWA, Y. Hasegawa \& T. IKaI: Herbimycin, a new antibiotic produced by a strain of Streptomyces. J. Antibiotics 32: 255 261, 1979

2) Ömura, S.; A. Nakagawa \& N. Sadakane: Structure of herbimycin, a new ansamycin antibiotic. Tetrahedron Lett. 1979: 4323 4326, 1979

3) Furusaki, A.; T. Matsumoto, A. Nakagawa \& S. OMURA: Herbimycin A: An ansamycin antibiotic; X-ray crystal structure. J. Antibiotics 33: 781 782, 1980

4) Iwai, Y.; A. Nakagawa, N. Sadakane, S. Ömura, H. Ōiwa, S. Matsumoto, M. TAKahashi, T. IKaI \& Y. OchiaI: Herbimycin B, a new benzoquinonoid ansamycin with antiTMV and herbicidal activities. J. Antibiotics 33: 1114 1119, 1980

5) Uehara, Y.; M. Hori, T. Takeuchi \& H. 
UMEZAWA: Screening of agents which convert "Transformation morphology" of Rous sarcoma virus-infected rat kidney cells to "normal morphology". Identification of an active agent as herbimycin and its inhibition of intra cellular scr kinase. Jpn. J. Cancer Res. (Gann) 76: 672 675,1985

6) Tanida, S.; M. Muroi \& T. Hasegawa (Takeda Chem. Ind.): A new antibiotic and the process for production thereof. Jpn Kokai
102398 ('84), June 13, 1984

7) Tanida, S.; M. Muroi \& T. Hasegawa (Takeda Chem. Ind.): Antibiotic TAN-420. U.S. 4,540,517, Sept. 17, 1985

8) Tanida, S.; M. Muroi \& T. Hasegawa (Takeda Chem. Ind.): Antibiotic TAN-420, and its use. Eur. Pat. Appl. 110,710, June 13, 1984

9) DeBoer, C.; P. A. Meulman, R. J. Whuk \& D. H. Peterson: Geldanamycin, a new antibiotic. J. Antibiotics 23: 442 447, 1970 